\title{
KORELASI ANTARA TINGKAT KEMAMPUAN BERPIKIR KREATIF DENGAN KOMPETENSI PENGETAHUAN IPS
}

\author{
Cintya Puspita Sari ${ }^{1}$, I Wayan Sujana ${ }^{2}$, I Ketut Adnyana Putra ${ }^{3}$ \\ 1,2,3 Jurusan PGSD Universitas Pendidikan Ganesha Singaraja, Indonesia \\ e-mail: cintya.puspitasari@ymail.com ${ }^{1}$,iwayan.sujana@undiksha.ac.id², \\ ketut.adnyana.putra@undiksha.ac.id ${ }^{3}$
}

\begin{abstract}
ABSTRAK
Penelitian ini bertujuan untuk mengetahui korelasi antara tingkat kemampuan berpikir kreatif dengan kompetensi pengetahuan IPS siswa kelas V SD Gugus Kapten Kompyang Sujana tahun pelajaran 2017/2018. Jenis penelitian ini adalah penelitian ex post facto dengan jenis studi korelasi. Populasi dari penelitian ini adalah siswa kelas V yang berada di SDN Gugus Kapten Kompyang Sujana, Denpasar Barat tahun pelajaran 2017/2018 yang memiliki populasi sebanyak 637 orang. Penentuan sampel menggunakan teknik proporsional random sampling dengan taraf kesalahan $5 \%$ dan diperoleh jumlah sampel dari populasi adalah 227 orang. Data diperoleh melalui tes berpikir kreatif dan pencatatan dokumen nilai ujian akhir semester I mata pelajaran IPS siswa kelas V SD Gugus Kapten Kompyang Sujana. Analisis statistik yang digunakan pada penelitian ini adalah uji hipotesis menggunakan analisis korelasi triserial. Berdasarkan analisis maka rpts $_{\text {ket }}=1,005$. Pada taraf signifikansi $5 \%$ dengan $n=227$, maka diperoleh $\mathrm{rpts}_{\mathrm{tab}}=1,960$. Hasil tersebut menunjukkan $\mathrm{rpts}_{\mathrm{ket}}=1,005<\mathrm{rpts}_{\mathrm{tab}}=1,960$ maka dapat diartikan bahwa $\mathrm{H}_{0}$ yang berbunyi tidak terdapat korelasi yang signifikan antara tingkat kemampuan berpikir kreatif dengan kompetensi pengetahuan IPS siswa kelas V SD Gugus Kapten Kompyang Sujana tahun pelajaran 2017/2018 diterima. Jadi dapat disimpulkan bahwa tidak terdapat korelasi yang signifikan antara tingkat kemampuan berpikir kreatif dengan kompetensi pengetahuan IPS siswa kelas V SD Gugus Kapten Kompyang Sujana tahun pelajaran 2017/2018.
\end{abstract}

Kata kunci: tingkat kemampuan berpikir kreatif, kompetensi pengetahuan IPS, siswa kelas 5 SD.

\begin{abstract}
This study aimed to determine the correlation between level of creative thinking ability with social knowledge competency of students of grade V in elementary school Gugus Kapten Kompyang Sujana in the lesson year 2017/2018. The type of this research was ex post facto. The method used in this research is descriptive method with correlation study type. Research populations were all students grade 5 in elementary school Gugus Kapten Kompyang Sujana academic period 2017/2018 which has population over 637 students. Sample was determined by proportional technique random sampling with the level of error $5 \%$ and the number of sample gained from the populations were 227 students. The data were obtained through the results of a creative thinking essay test which was answered by the respondents. The statistical analysis used in this research is hypothesis test using triserial correlation analysis. Based on the result of analysis then $r p t s_{\text {count }}=1,005$. At a level of signification $5 \%$ with $\mathrm{n}=227$, then obtained $r_{\text {table }}=1,960$. Because $r_{\text {count }}=1,005>r_{\text {table }}=1,960$ it means that $\mathrm{H}_{0}$ that said there is no significant correlation between level of creative thinking ability with social knowledge competency of students of grade V in elementary school Gugus Kapten Kompyang Sujana in the lesson year 2017/2018 was accepted. The conclusion was there is no correlation between level of creative thinking ability with social knowledge competency of students of grade $\mathrm{V}$ elementary school Gugus Kapten Kompyang Sujana in the lesson year 2017/2018.
\end{abstract}

Keywords: level of creative thinking ability, social knowledge competency, students of grade $\mathrm{V}$ elementary school. 


\section{Pendahuluan}

Kurikulum merupakan perangkat yang berkaitan dengan tujuan pendidikan, sekaligus merupakan pedoman dalam pe-laksanaan pengajaran pada semua kelas dan tingkat pendidikan. Kurikulum menjadi faktor penting dalam proses pendidikan di setiap lembaga pendidikan. Apa yang di-kemukakan di atas mendukung pendapat yang dikemukakan oleh Ghufron (2017: 195) "dalam melaksanakan kurikulum se-kolah harus mampu menjadikan proses belajar yang menarik dan mampu memu-puk kreativitas siswa dengan efektif".

Upaya yang terencana untuk men-cerdaskan kehidupan bangsa sangat di-perlukan maka sejak dini siswa harus di-bimbing dan dikembangkan secara opti-mal segala aspeknya, yaitu aspek kognitif, afektif dan psikomotoriknya. Hal tersebut bertujuan agar siswa di sekolah dasar mampu mengembangkan dan menyela-raskan segala kreativitas baik dalam segi ide kreatif, sikap kreatif maupun keteram-pilan kreatif siswa. Susanto (2013:85) menyatakan, pendidikan adalah upaya yang terorganisasi, berencana dan berlangsung secara terus menerus se-panjang hayat untuk membina pe-serta didik menjadi manusia pari-purna, dewasa, dan berbudaya. Un-tuk mencapai pembinaan ini asas pendidikan harus berorientasi pada pengembangan seluruh aspek po-tensi peserta didik, diantaranya aspek kognitif, afektif, dan berim-plikasi pada aspek psikomotorik.

Berdasarkan uraian di atas maka faktor penting dari kurikulum yang berkaitan dengan tujuan pendidikan dan tingkat pendidikan adalah segala kegiatan kependidikan mencakup ilmu pengetahu-an yang berpusat pada siswa dalam proses belajar yang menarik, inovatif dan kreatif. Kegiatan pembelajaran perlu dila-kukan dengan memerhatikan beberapa aspek penting, yaitu: a) berpusat pada siswa; b) mengembangkan kreativitas sis-wa; c) menciptakan kondisi belajar yang menyenangkan dan menantang, d) mem-berikan pengalaman yang berharga. Pe-ngembangan kurikulum juga sangat me-merlukan pendekatan mata pelajaran karena kemampuan berpikir siswa akan terlatih dan terasah.

"Pendekatan mata pelajaran dalam pengembangan kurikulum adalah pende-katan dalam pengembangan kurikulum yang mengutamakan pengembangan ma-tapelajaran yang dipandang mampu me-latih kemampuan berpikir manusia agar bebas mengarungi kehidupan" (Toenlioe, 2017:132). Kemampuan berpikir kreatif siswa sangat perlu dioptimalkan sehingga matapelajaran yang mengacu pada ke-mampuan berpikir siswa dipandang perlu. Salah satu mata pelajaran yang dapat dijadikan sebagai sarana untuk mengem-bangkan kreativitas adalah IPS. Matape-lajaran IPS sangat memungkinkan untuk melatih siswa mampu berpikir logis, kritis, detail, sistematis, kreatif, dan inovatif.

Ruseffendi (dalam Susanto, 2017: 24) menyatakan manusia memiliki intele-gensi yang terdiri dari tujuh kemampuan mental pokok, yaitu kecepatan menga-mati, fasih dalam katakata, penalaran, ingatan, kemampuan tilikan ruang, ke-mampuan verbal dan kemampuan me-ngenal bilangan. Empat dari kemampuan mental tersebut erat kaitannya dengan pembelajaran IPS, yaitu kecepatan me-ngamati, penalaran, kemampuan tilikan ruang, dan kemampuan mengobservasi. Kemampuan-kemampuan mental itu me-miliki peran penting dalam mengembang-kan kreativitas siswa karena keempat kemampuan mental tersebut erat kaitan-nya dengan pembelajaran IPS, maka bisa dikatakan bahwa IImu Pengetahuan Sosial berpotensi mengembangkan kemam-puan berpikir kreatif siswa.

Kemampuan berpikir kreatif siswa dalam pembelajaran IPS mampu terimple-mentasi dengan baik apabila saat proses pembelajaran siswa dapat menuangkan segala pimikiran kreatifnya dalam meme-cahkan masalah dan materi yang sedang diajarkan. Saat materi dan tugas-tugas yang diberikan memberikan kesempatan siswa mencari dari sumber buku, fasilitas yang disediakan dan berpikir seluwes-luwesnya maka siswa akan mampu mencapai tujuan dari pengembangan ku-rikulum dan mencapai target-target terten-tu proses pendidikan khususnya dalam kompetensi pengetahuan IPS. Apa yang dikemukakan tersebut mendukung pen-dapat Susanto (2013: 156) yang menya-takan "melalui pembelajaran IPS hendak-nya dapat membantu siswa memperoleh informasi, ide, keterampilan, nilai, dan ca-ra berpikir". 
Menurut Zubaedi (2017:122) "anak-anak yang ber-IQ tinggi mempunyai ke-mampuan berpikir convergent (berpikir untuk mencari jawaban yang benar), se-dangkan anak-anak yang sangat kreatif mempunyai kemampuan berpikir diver-gent (imaginative, mencari variasi/ alter-natif jawaban dan mencari sesuatu yang baru)". Susanto (2017:23) menyatakan "pengajaran di sekolah pada umumnya terbatas pada penalaran verbal dan pemikiran logis, pada tugas-tugas yang ha-nya menuntut pemikiran konvergen. Proses pemikiran tinggi termasuk berpikir kreatif jarang dilatih".

Munandar (1999) mengemukakan ciri-ciri kemampuan berpikir kreatif yang berhubungan dengan kognisi dapat dilihat dari keterampilan berpikir lancar, keteram-pilan berpikir luwes, keterampilan berpikir orisional, keterampilan elaborasi, dan ke-terampilan menilai. Penjelasan dari ciri-ciri yang berkaitan dengan keterampilan ter-sebut diuraikan sebagai berikut. (1) Ciri-ciri keterampilan kelancaran yaitu: men-cetuskan banyak gagasan dalam peme-cahan masalah, memberikan banyak ja-waban dalam menjawab suatu pertanya-an, memberikan banyak cara atau saran untuk melakukan berbagai hal, bekerja lebih cepat dan melakukan lebih banyak dari pada siswa-siswa lain. (2) Ciri-ciri keterampilan berpikir luwes (fleksibel) yaitu: menghasilkan variasi-variasi gaga-san penyelesaian masalah atau jawaban suatu pertanyaan, dapat melihat suatu masalah dari sudut pandang yang berbeda-beda, menyajikan suatu konsep dengan cara yang berbeda-beda. (3) Ciri-ciri keterampilan orisional (keaslian) yaitu: memberikan gagasan yang relatif baru dalam menyelesaikan masalah atau jawa-ban yang lain dari yang sudah biasa da-lam menjawab suatu pertanyaan, mem-buat kombinasi-kombinasi yang tidak lazim dari bagian-bagian atau unsur-unsur. (4) Ciri-ciri keterampilan mempe-rinci (elaborasi) yaitu: mengembangkan atau memperkaya gagasan orang lain, menambahkan, menata atau memperinci suatu gagasan sehingga meningkatkan kualitas gagasan tersebut. (5) Ciri-ciri keterampilan menilai (mengevaluasi) yaitu: dapat menemukan kebenaran suatu pertanyaan atau kebenaran suatu rencana penyelesaian masalah (justification), da-pat mencetuskan gagasan penyelesaian suatu masalah dan dapat melaksanakan dengan benar. Mempunyai alasan yang dapat dipertanggungjawabkan untuk men-capai suatu keputusan.

Berdasarkan uraian di atas maka tingkat kemampuan berpikir kreatif adalah pengembangan dari tahap tingkat berpikir mengingat, memahami, dan menerapkan. Tingkat kemampuan berpikir kreatif me-libatkan aktivitas mental dalam memper-timbangkan suatu informasi dan ide-ide baru. Tingkat kemampuan berpikir kreatif dalam prosesnya adalah memahami ma-salah dan mengomunikasikan ide berda-sarkan pertimbangan. Tingkat kemam-puan berpikir kreatif yang digunakan da-lam penelitian ini adalah tinggi, sedang dan rendah.

Fakta yang ditemukan di lapangan membuktikan bahwa khususnya di seko-lah dasar masih banyak terdapat tugas-tugas dari mata pelajaran IPS yang me-nuntut siswa berpikir secara konvergen. Siswa yang terlatih berpikir secara konver-gen menyebabkan proses berpikir kreatif menjadi terbatas dan hanya bersifat ob-jektif yaitu pemikiran yang mengacu pada satu jawaban ataupun jawaban yang be-nar atau salah. Terbatasnya kemampuan berpikir siswa menyebabkan tujuan dari pengembangan kurikulum dan tujuan dari pendidikan menjadi kurang terimplemen-tasi. Kompetensi pengetahuan IPS terca-pai dengan baik apabila pembelajaran yang mengacu pada tingkat kemampuan berpikir kreatif bisa dikembangkan.

Penelitian ini menggunakan tes yang berupa tes esai dan penelitian dila-kukan untuk mengetahui korelasi antara tingkat kemampuan berpikir kreatif deng-an kompetensi pengetahuan IPS, peneli-tian ini dilakukan dengan judul "Korelasi Antara Tingkat Kemampuan Berpikir Krea-tif dengan Kompetensi Pengetahuan IPS Siswa Kelas V SD Gugus Kapten Kom-pyang Sujana Tahun Pelajaran 2017/ 2018".

\section{METODE}

Penelitian ini merupakan penelitian "ex post facto" dengan jenis studi korelasi dan tujuan dari penelitian ini untuk menge-tahui korelasi antara tingkat kemampuan berpikir 
kreatif dengan kompetensi penge-tahuan IPS tanpa memanipulasi variabel be-bas atau menggali fakta yang sudah terja-di sebelumnya. Populasi dalam penelitian ini adalah siswa kelas V SD Gugus Kapten Kompyang Sujana tahun pelajaran 2017/2018 yang berjumlah 637 siswa.

Berdasarkan tabel Issac and Mic-hael, jumlah sampel yang diambil berda-sarkan tingkat kesalahan $5 \%$ berjumlah 227 orang siswa. Pengambilan sampel dalam penelitian ini menggunakan teknik proporsional random sampling yang dila-kukan untuk menjamin representatif sam-pel jika jumlah subjek tidak sama dalam pengambilan sampel yang dilakukan un-tuk memperoleh informasi dari perwakilan rerata semua individu dalam populasi.

Metode yang digunakan dalam pe-ngumpulan data adalah metode tes dan non tes, jenis tes yang digunakan dalam penelitian ini yaitu tes esai dan jenis non tes yang digunakan dalam penelitian ini adalah pencatatan dokumen. Penelitian ini dilakukan sesuai dengan data yang di-kumpulkan, Tes esai dalam penelitian ini menggunakan tes esai berpikir kreatif un-tuk mengetahui dan mengukur kemampu-an kognitif siswa dalam kompetensi pe-ngetahuan yaitu Kompetensi Inti 3 (KI-3). Tes berpikir kreatif ini menggunakan kom-ponen indikator dan subtes yang sudah terstandar serta menggunakan rubrik pe-nilaian, sedangkan pencatatan dokumen berupa absen siswa, jumlah siswa dan nilai rapor kompetensi inti pengetahuan IPS kelas V SD Gugus Kapten Kompyang Su-jana, Denpasar Barat semester I.

Analisis dalam penelitian ini meng-gunakan analisis statistik inferensial. Tek-nik analisis data yang digunakan adalah teknik korelasi triserial. Teknik triserial ini digunakan untuk mencari hubungan dua variabel yaitu variabel bebas dan variabel terikat. Teknik korelasi yang digunakan bertujuan untuk mencari koefisien korelasi antara gejala nominal dengan gejala inter-val. Uji hipotesis statistik menggunakan korelasi triserial dengan mengetes antara variabel bebas $(X)$ dan variabel terikat $(Y)$. Hipotesis yang diuji dalam penelitian ini adalah $\mathrm{H}_{0}$ yang berbunyi tidak terdapat korelasi yang signifikan antara tingkat ke-mampuan berpikir kreatif dengan kompe-tensi pengetahuan IPS siswa kelas V SD Gugus Kapten Kompyang Sujana tahun pelajaran 2017/2018. Kriteria yang digu-nakan dalam pengujian korelasi triserial ini yaitu dengan menggunakan taraf signifi-kansi $5 \%$. Adapun ketentuan yang diuji dalam penelitian ini jika rpts $_{\text {ket }}>$ rpts $_{\text {tab }}$ ma-ka $\mathrm{H}_{0}$ yang berbunyi tidak terdapat korela-si antara tingkat kemampuan berpikir kreatif dengan kompetesi pengetahuan IPS ditolak, sebaliknya jika $\mathrm{rpts}_{\mathrm{ket}}<\mathrm{rpts}_{\mathrm{tab}}$ maka $\mathrm{H}_{0}$ yang berbunyi berbunyi tidak ter-dapat korelasi antara tingkat kemampuan berpikir kreatif dengan kompetesi penge-tahuan IPS diterima.

\section{Hasil dan Pembahasan}

\section{Deskripsi Data Tingkat Kemampuan Berpikir Kreatif}

Data tentang tingkat kemampuan berpikir kreatif siswa kelas V SD Gugus Kapten Kompyang Sujana diperoleh mela-lui penyebaran tes esai berpikir kreatif. Sampel yang dibagikan tes esai berpikir kreatif sebanyak 227 responden dan dibe-rikan 5 sub tes esai. Hasil nilai dari tes berpikir kreatif disajikan melalui tabel se-bagai berikut.

Tabel 1. Deskripsi Data Nilai Tes Tingkat Kemampuan Berpikir Kreatif

\begin{tabular}{cc}
\hline Data Statistik & Nilai \\
\hline Mean & 77,97 \\
Modus & 75 \\
Median & 78 \\
Skor Minimum & 60 \\
Skor Maksimum & 95 \\
\hline
\end{tabular}


Berdasarkan data nilai tes berpikir kreatif siswa kelas V SD Gugus Kapten Kompyang Sujana tahun pelajaran 2017/ 2018 mendapatkan nilai rata-rata 77,97. Nilai tes berpikir kreatif yang tertinggi 95 dan yang terendah 60. Data nilai siswa dapat dilihat dalam bentuk grafik sebagai berikut:

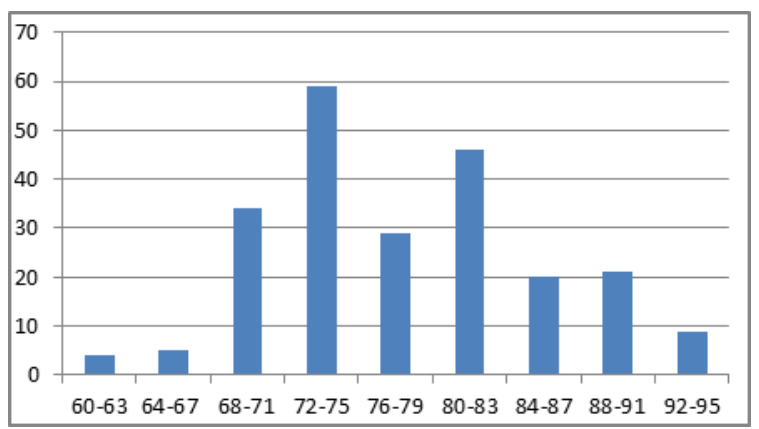

Gambar 1. Histogram Data Tingkat Kemampuan Berpikir Kreatif

Berdasarkan histogram tentang data berpikir kreatif dapat diketahui bahwa frekuensi nilai terbanyak terdapat pada kelas interval ke-4, selanjutnya dapat dili-hat tingkat kategori berpikir kreatif siswa kelas V SD Gugus Kapten Kompyang Su-jana tahun pelajaran 2017/2018 sebagai berikut:

Tabel 2. Pedoman Konversi PAP Skala Lima tentang Tingkat Kemampuan Berpikir Kreatif

\begin{tabular}{cc}
\hline Rentang & Kategori \\
\hline $90-100$ & Sangat Baik \\
$80-89$ & Baik \\
$65-79$ & Cukup Baik \\
$55-64$ & Kurang Baik \\
$0-54$ & Sangat Kurang Baik \\
\hline
\end{tabular}

(Sumber: Agung,2014)

Berdasarkan kategori tingkat kemam-puan berpikir kreatif di atas serta hasil analisis data, bahwa rerata dari tingkat ke-mampuan berpikir kreatif siswa kelas V Gugus Kapten Kompyang Sujana adalah 77,97. Berdasarkan data tersebut maka dapat disimpulkan bahwa nilai tingkat ke-mampuan berpikir kreatif siswa kelas V SD Gugus Kapten Kompyang Sujana, ter-golong kategori cukup kreatif.

\section{Deskripsi Data Kompetensi Pengetahu-an IPS}

Data tentang nilai kompetensi penge-tahuan IPS diperoleh dari pencatatan dokumen melalui nilai ujian akhir semester 1 siswa kelas V SD Gugus Kapten Kom-pyang Sujana, Denpasar Barat tahun pe-lajaran 2017/2018. Sampel yang diguna-kan dalam penelitian ini berjumlah 227 orang siswa. Hasil nilai kompetensi pe-ngetahuan IPS disajikan dengan Microsoft excel 2010 serta secara manual yang di-masukkan ke dalam tabel sebagai berikut.

Tabel 3. Deskripsi Data Nilai Kompetensi Pengetahuan IPS Siswa

\begin{tabular}{cc}
\hline Data Statistik & Nilai \\
\hline Mean & 78,03 \\
Modus & 73 \\
Median & 77 \\
Skor Minimum & 62 \\
Skor Maksimum & 94 \\
\hline
\end{tabular}


Berdasarkan data nilai kompetensi pengetahuan IPS di kelas rata-rata siswa kelas V SD Gugus Kapten Kompyang Su-jana Tahun Pelajaran 2017/2018 menda-patkan nilai 78,03. Nilai kompetensi pe-ngetahuan IPS di kelas tertinggi 94 dan yang terendah 62. Dari data di atas dapat juga dilihat dalam bentuk grafik, sehingga dapat dilihat sebagai berikut:

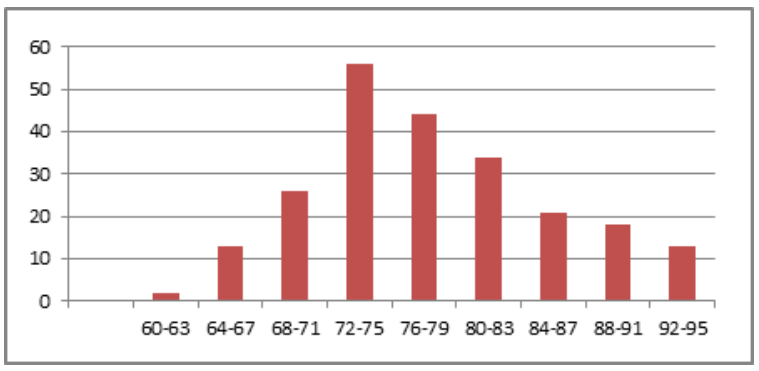

Gambar 2. Histogram Data Interaksi Sosial di Kelas

Berdasarkan histogram tentang data kompetensi pengetahuan IPS di ke-las dapat diketahui bahwa frekuensi nilai terbanyak terdapat pada kelas interval ke-4, selanjutnya dapat dilihat data berikut ini tentang tingkat kategori kompetensi pe-ngetahuan IPS di kelas siswa kelas V SD Gugus Kapten Kompyang Sujana Tahun Pelajaran 2017/ 2018.

Tabel 4. Pedoman Konversi PAP Skala Lima Kompetensi Pengetahuan IPS

\begin{tabular}{cc}
\hline Persentase Kompetensi Pengetahuan & Kriteria Kompetensi Pengetahaun IPS \\
IPS & Sangat Baik \\
$90-100$ & Baik \\
$80-89$ & Cukup Baik \\
$65-79$ & Kurang Baik \\
$55-64$ & Sangat Kurang Baik \\
$0-54$ &
\end{tabular}

(Sumber: Agung, 2014)

Berdasarkan kategori kompetensi pe-ngetahuan IPS di atas serta hasil dari analisis data, bahwa rerata dari kompe-tensi pengetahuan IPS di kelas siswa ke-las V Gugus Kapten Kompyang Sujana adalah 78,03. Berdasarkan data tersebut maka dapat disimpulkan bahwa nilai kom-petensi pengetahuan IPS di kelas siswa kelas V SD Gugus Kapten Kompyang Sujana, tergolong kategori cukup baik.

Uji hipotesis yang dilakukan adalah uji hipotesis dengan menggunakan teknik analisis triserial (variabel $\mathrm{X}$ dengan varia-bel $\mathrm{Y}$ ), maka untuk tujuan analisis data dirumuskan dalam hipotesis nol $\left(\mathrm{H}_{0}\right)$. Hipo-tesis yang dirumuskan yaitu $\mathrm{H}_{0}$ yang ber-bunyi tidak terdapat korelasi yang signifi-kan antara tingkat kemampuan berpikir kreatif dengan kompetensi pengetahuan IPS siswa kelas V SD Gugus Kapten Kompyang Sujana Tahun Pelajaran 2017/ 2018.

Berdasarkan hasil analisis data deng-an menggunakan rumus triserial dan di-bantu menggunakan microsoft excel 2010 serta menghitung secara manual dipero-leh rpts $_{\text {ket }}=1,005$ sedangkan uji koefisien korelasi untuk $n=227$, pada taraf signifi-kansi $5 \%$ diperoleh rpts $_{\text {tab }}=1,960$ yang be-rarti rpts $_{\text {ket }}<$ rpts $_{\text {tab }}$, sehingga $H_{0}$ yang ber-bunyi tidak terdapat korelasi antara tingkat kemampuan berpikir kreatif dengan kom-petensi pengetahuan IPS diterima. Dapat disimpulkan bahwa tidak terdapat korelasi yang signifikan antara tingkat kemampuan berpikir kreatif dengan kompetensi penge-tahuan IPS siswa kelas V SD Gugus Kap-ten Kompyang Sujana tahun pelajaran 2017/2018. Berdasarkan uraian di atas maka kompetensi pengetahuan IPS siswa tidak ditentukan oleh tingkat kemampuan berpikir kreatif yang tinggi, sedang dan rendah yang dimiliki siswa tersebut. 
Berdasarkan hasil analisis dipero-leh rpts $_{\text {ket }}=1,005$ dan uji koefisien korelasi untuk $\mathrm{n}=227$, pada taraf signifi-kansi $5 \%$ diperoleh rpts $_{\text {tab }}=1,960$ sehingga $\mathrm{rpts}_{\text {ket }}=$ $1,005<$ rpts $_{\mathrm{tab}}=1,960$ yang berarti $\mathrm{rpts}_{\mathrm{ket}}<\mathrm{rpts}_{\mathrm{tab}}$, maka $\mathrm{H}_{0}$ yang berbunyi tidak terda-pat hubungan yang signifikan antara ting-kat kemampuan berpikir kreatif dengan kompetensi pengetahuan IPS siswa kelas V SD Gugus Kapten Kompyang Sujana tahun pelajaran 2017/2018 diterima. Ber-dasarkan uraian tersebut maka dapat di-katakan bahwa setiap siswa memiliki ke-cenderungan untuk menguasai kompeten-si pengetahuan IPS yang tidak ditentukan oleh tingkat kemampuan berpikir kreatif.

Selain berpikir kreatif kompetensi pengetahuan IPS bisa disebabkan oleh adanya spontanitas dalam merespon se-suatu, faktor lingkungan, gaya belajar, fa-silitas belajar, sarana prasarana, pola as-uh orang tua, kemampuan memecahkan masalah, berpikir kritis, peka dan tanggap untuk bertindak secara rasional. Selain itu peran guru dan kurikulum sangat berpe-ngaruh dengan hasil belajar siswa khu-susnya dalam kompetensi pengetahuan IPS, seperti yang dinyatakan Towaf(2014) bahwa keefektifan matapelajaran IPS ber-gantung pada tingkat penguasaan kuriku-lum, etos kerja guru dan kinerja guru dalam mengelola pembelajaran IPS dan menciptakan situasi kondusif di lingku-ngan sekolah. Banyaknya faktor-faktor yang menyebabkan kompetensi pengeta-huan IPS tercapai optimal.

Faktor-faktor yang mempengaruhi hasil belajar siswa dalam kompetensi pe-ngetahuan IPS yaitu faktor internal dan faktor eksternal. Susanto (2013) menyata-kan bahwa faktor internal merupakan fak-tor yang bersumber dari dalam diri peserta didik, yang memengaruhi kemampuan be-lajarnya. Faktor internal ini meliputi: kecer-dasan, minat dan perhatian, motivasi bela-jar, ketekunan, sikap, kebiasaan belajar, serta kondisi fisik dan kesehatan. Kecer-dasan merupakan kemampuan siswa yang mempengaruhi cepat atau lambat-nya siswa dalam menerima informasi dan kemampuan dalam terpecahkan atau ti-daknya suatu masalah karena dalam pembelajaran IPS kecerdasan siswa sa-ngat mempengaruhi hasil belajarnya. Mi-nat dan perhatian siswa dalam pembelaja-ran IPS merupakan kegairahan atau kei-nginan tinggi siswa karena dengan minat yang besar sangat mempengaruhi siswa dalam memahami suatu materi yang ter-dapat dalam pembelajaran IPS, begitu ju-ga dengan motivasi belajar yang menye-babkan siswa menjadi giat dan termotivasi untuk mencapai keberhasilan belajar. Ke-tekunan, sikap, kebiasaan belajar, serta kondisi fisik dan kesehatan siswa sangat berperan penting dalam keberhasilan be-lajarnya khususnya kompetensi pengeta-huan IPS karena siswa yang tekun belajar dan mempunyai sikap yang pantang me-nyerah dalam memahami masalah dan selalu membiasakan diri untuk belajar ser-ta didukung oleh kondisi fisik dan keseha-tan yang baik akan sangat membantu sis-wa dalam memperoleh hasil belajar yang optimal.

Faktor eksternal adalah faktor yang berasal dari luar diri peserta didik dan mempengaruhi hasil belajar yaitu ke-luarga, sekolah dan masyarakat. Keluarga adalah orang-orang terdekat yang sangat mempengaruhi keberhasilan belajar siswa khususnya kompetensi pengetahuan IPS karena dukungan, motivasi dan fasilitas belajarnya. Motivasi dan Fasilitas dari orang tua yang mendukung pembelajaran anak sangat diperlukan agar dalam kese-harian termasuk di rumah siswa bisa bela-jar, serta apa yang dipelajarinya bersama orang tua bisa diterapkan di sekolah dan lingkungan bermain siswa khususnya pembelajaran IPS agar tercapainya hasil belajar yang optimal. Selain keluarga, pe-ran sekolah khususnya guru sangat ber-peran penting dalam tercapainya hasil be-lajar yang optimal karena pribadi dan si-kap guru yang kreatif, inovatif, ramah, membimbing dengan penuh kasih sayang dan bertanggungjawab atas apa yang di-lakukan menjadi sosok yang ditiru dan di-gugu oleh siswa sehingga dalam pengelo-laan kelas dan saat menjelaskan materi guru sangat berperan penting agar siswa bisa memahami pembelajaran khususnya pembelajaran IPS sehingga bisa tercapai-nya kompetensi pengetahuan IPS yang optimal. Penerapan pembelajaran di kelas khususnya matapelajaran IPS ke dalam kehidupan seharihari siswa yaitu lingku-ngan dan teman sepermainan siswa sa-ngat berpengaruh dengan tercapainya kompetensi pengetahuan IPS karena da-lam proses belajar dan bermain di luar ke-las siswa bisa menerapkan pembelajaran-nya di kelas ke lingkungan bermain bersa-ma teman-temannya. 
Berdasarkan uraian di atas maka hasil belajar siswa khususnya dalam kom-petensi pengetahuan IPS dipengaruhi oleh dua faktor yaitu faktor internal dan faktor eksternal. Faktor internal adalah faktor yang mempengaruhi hasil belajar dan disebabkan oleh diri siswa itu sendiri, sedangkan faktor eksternal adalah faktor yang mempengaruhi hasil belajar dan di-sebabkan oleh luar diri siswa. Faktor inter-nal terdiri dari adanya spontanitas dalam merespon sesuatu, kecerdasan, sikap, ke-tekunan, kondisi fisik, kesehatan, kesia-pan belajar, psikologis, minat, bakat, moti-vasi belajar, perhatian, berpikir kritis, ke-mampuan memecahkan masalah, peka dan tanggap untuk bertindak secara rasio-nal. Faktor eksternal terdiri dari faktor ke-luarga, sekolah, masyarakat, teman se-permainan, waktu, tugas, lingkungan, ga-ya belajar, fasilitas belajar, sarana prasa-rana, pola asuh orang tua, guru dan kuri-kulum. Banyaknya faktor-faktor yang me-nyebabkan kompetensi pengetahuan IPS tercapai optimal berarti bahwa kompeten-si pengetahuan IPS tidak hanya ditentu-kan oleh tingkat kemampuan berpikir kre-atif. Berdasarkan hasil belajar kompetensi pengetahuan IPS yang diperoleh, siswa masih menggunakan tes yang bersifat objektif dan dituntut untuk berpikir secara konvergen sehingga kemampuan siswa masih terbatas dengan soal-soal yang bersifat objektif.

\section{Simpulan dan Saran}

Hasil analisis menunjukan bahwa tidak terdapat korelasi yang signifikan antara tingkat kemampuan berpikir kreatif de-ngan kompetensi pengetahuan IPS siswa kelas V SD Gugus Kapten Kompyang Su-jana tahun pelajaran 2017/2018. Hasil analisis data dengan menggunakan micro-soft excel 2010 dan menghitung secara manual diperoleh rpts $_{\text {ket }}=1,005$ dan uji koefisien korelasi untuk $n=227$, pada taraf signifikansi $5 \%$ diperoleh $\mathrm{rpts}_{\mathrm{tab}}=1,960 \mathrm{se}$ hingga $\mathrm{rpts}_{\mathrm{ket}}=1,005<\mathrm{rpts}_{\mathrm{tab}}=1,960$ yang berarti $\mathrm{rpts}_{\mathrm{ket}}<r p t \mathrm{stab}_{\mathrm{tab}}$, sehingga $\mathrm{H}_{0}$ yang berbunyi tidak terdapat korelasi antara tingkat kemampuan berpikir kreatif de-ngan kompetensi pengetahuan IPS diteri-ma. Dapat disimpulkan bahwa tidak terda-pat korelasi yang signifikan antara tingkat kemampuan berpikir kreatif dengan kom-petensi pengetahuan IPS siswa kelas V SD Gugus Kapten Kompyang Sujana ta-hun pelajaran 2017/2018. Berdasarkan uraian di atas maka kompetensi pengeta-huan IPS siswa tidak ditentukan oleh ting-kat kemampuan berpikir kreatif yang ting-gi, sedang dan rendah yang dimiliki siswa tersebut.

Adapun saran yang disampaikan ada-lah sebagai berikut: (1) Kepada siswa, berdasarkan temuan penelitian yang dipe-roleh disarankan siswa untuk berani mengungkapkan pendapat dan ide-ide kreatif sehingga siswa mampu dalam memberi-kan suatu inovasi dan kreativitas baru se-hingga tujuan dari pembelajaran dan kom-petensi siswa bisa optimal. (2) Kepada gu-ru, berdasarkan temuan penelitian yang diperoleh disarankan kepada guru untuk mengetahui tingkat kemampuan berpikir kreatif siswa dan jenis tes yang digunakan untuk mengukur tingkat kemampuan ber-pikir kreatif siswa sehingga dalam pembe-lajaran guru bisa optimal dalam membim-bing dan mengarahkan siswa khususnya siswa agar berani mengemukakan penda-pat dan ide-ide kreatifnya. (3) Kepada se-kolah, berdasarkan temuan penelitian di-sarankan kepada kepala sekolah dan guru wali kelas agar dapat menggunakan hasil penelitian ini sebagai pendukung guru terutama dalam tes yang digunakan untuk mengukur tingkat kemampuan berpikir kreatif siswa. (4) Kepada peneliti lain agar hasil penelitian ini digunakan sebagai re-ferensi untuk melaksanakan penelitian se-lanjutnya dengan menggunakan tes yaitu tes esai berpikir kreatif dan semoga bisa bermanfaat untuk seluruh masyarakat. 


\section{DAFTAR RUJUKAN}

Darusman, R. (2014). Penerapan metode mind mapping (peta pikiran) untuk meningkatkan kemampuan berpikir kreatif matematik siswa SMP. Infinity Journal, 3(2), 164-173.

Fauziah, Y. N. (2011). Analisis Kemampuan Guru dalam Mengembangkan Keterampilan Berpikir Kreatif Siswa Sekolah Dasar Kelas V pada Pembelajaran IImu Pengetahuan Alam. Jurnal Edisi Khusus, 1(1), 98-106.

Manu, T. S. N., \& Nomleni, F. T. (2018). Pengaruh Metode Pembelajaran Karya Kelompok Terhadap Keterampilan Proses Sains Dengan Kovariabel Kemampuan Berpikir Kreatif Siswa Pada Mata Pelajaran Biologi. Scholaria: Jurnal Pendidikan dan Kebudayaan, 8(2), 167-179.

Nugroho, R. N. C. (2011). Penggunaan Metode Pembelajaran Mind Map untuk Meningkatkan Kreativitas dan Hasil Belajar Ekonomi Siswa Kelas x di SMA MTA Surakarta Tahun ajaran 2010/2011 (Doctoral dissertation, UNIVERSITAS SEBELAS MARET).

Ghufron, Moh. 2017. Filsafat Pendidikan. Cetakan Ke-1. Yogyakarta: Kalimedia.

Munandar, Utami. 1999. Pengembangan Kreativitas Anak Berbakat. Jakarta: Pusat Perbukuan Departemen Pendidi-kan dan Kebudayaan dengan PT Rine-ka Cipta.

Saefudin, A. A. (2012). Pengembangan kemampuan berpikir kreatif siswa dalam pembelajaran matematika dengan pendekatan pendidikan matematika realistik indonesia (PMRI). Jurnal Al-Bidāyah, 4(1).

Saifudin, M. H. (2012). Upaya Peningkatan Hasil Belajar dan Kreativitas Siswa Melalui Pembelajaran Peta Konsep pada Mata Pelajaran IPS Kelas V SDN Tuntang 02 Kecamatan Tuntang Kabupaten Semarang Tahun Pelajaran 2011/2012 (Doctoral dissertation, Program Studi Pendidikan Guru Sekolah Dasar FKIP-UKSW).

Samsiyah, N., \& Rudyanto, H. E. (2015). Kemampuan Berpikir Kreatif Dalam Memecahkan Masalah Matetatika Open-Ended Ditinjau Dari Tingkat Kemampuan Matematika Siswa Sekolah Dasar. PEDAGOGIA: Jurnal Pendidikan, 4(1), 23-33.

Silaban, R., \& Napitupulu, M. A. (2012). Pengaruh media mind mapping terhadap kreativitas dan hasil belajar kimia siswa SMA pada pembelajaran menggunakan advance organizer. -

Siswono, T. Y. E. (2004). Mendorong Berpikir Kreatif Siswa Melalui Pengajuan Masalah (Problem Posing). Makalah dipresentasikan pada Konferensi Nasional Matematika XI, Universitas Udayana Denpasar, 23-27.

Susanto, Ahmad. 2013. Teori Belajar dan Pembelajaran di Sekolah Dasar. Cetakan Ke-1. Jakarta: Prenadamedia Group.

Susanto, Ahmad. 2017. "Pendidikan IPS: Upaya Mengembangkan Kemampuan Berpikir Kreatif". Makalah disajikan dalam Prosiding Diskusi Panel Pendi-dikan 'Menjadi Guru Pembelajar’, Ke-luarga Alumni Universitas Indraprasta PGRI, Jakarta 8 April 2017. 
Toenlioe, Anselmus JE. 2017. Pengem-bangan Kurikulum. Cetakan Ke-1. Bandung: PT Refika Aditama.

Towaf, Siti Malikhah. 2014. "Pendidikan Karakter Pada Mata pelajaran IImu Pengetahuan Sosial”, Jilid 20, Nomor 1. Diakses 13 Desember 2017.

Zubaedi. 2017. Strategi Taktis Pendidikan Karakter (untuk PAUD dan Sekolah). Cetakan Ke1. Depok: Rajawali Pers. 